\title{
Goals of Elites and Local Communities in the European Union Neo-endogenous Development: Differences as the Constraints on Europeanisation?
}

\author{
Marek FURMANKIEWICZ ${ }^{1, *}$ Karolina KRÓLIKOWSKA ${ }^{2}$ and Katarzyna PRZYBYŁA ${ }^{1}$ \\ 1 Wroclaw University of Environmental and Life Sciences, Wrocław, Poland; \\ marek.furmankiewicz@upwr.edu.pl; katarzyna.przybyla@upwr.edu.pl \\ 2 WSB University in Wroclaw, Wroclaw, Poland; karolina.krolikowska@wsb.wroclaw.pl \\ * Correspondence: marek.furmankiewicz@upwr.edu.pl; marfurm@interia.pl
}

\begin{abstract}
Financial support for the Local Action Groups (territorial partnerships for local development, LAGs) is an element of the European Union (EU) place-based policy, which seeks to strengthen social participation in local governance with simultaneous consideration of the goals set by the EU development strategies. However, the neo-endogenous development is mostly based on local goals and needs, which are not always fully in line with the objectives of the EU governing elites. This paper addresses the hypothesis that the difficulties in the EU objectives implementation arise, among other reasons, from the differences between the goals, priorities, needs and knowledge of both the local communities and the governing elites. Neo-endogenous development attempts to overcome this problem by supporting local activities which are in line with the objectives of the EU policy. This paper presents the considerations based on the literature review supported by the archival data from the questionnaire survey performed in three LAGs case studies, as well as the analysis of their Local Development Strategies.
\end{abstract}

Keywords: territorial governance; neo-endogenous development; local communities' needs; governing elite's goals; Local Action Groups; Europeanisation

JEL Classification: L3; O15; P2

\section{Introduction}

In recent decades, an important feature of development policies in the European Union has been the growing importance of territorial governance structures, taking into account the principles of neo-endogenous and place-based development (Ray 2006; Słupińska 2013; Boukalova et al. 2016; Furmankiewicz and Campbell 2019). It was a response to the limitations of the top-down exogenous development typical for the mid-20th century, which in many aspects was ineffective in addressing the local socio-economic problems. The territorial partnership governance concept emphasizes the role of local needs, bottom-up initiatives, social activity and wider public participation in managing local resources (Shucksmith 2000; Adamski and Gorlach 2007). The EU LEADER initiative based partnerships, referred to as "Local Action Groups" (LAGs), are the main implementation tool for this type of governance in rural areas and have been widely discussed in the literature. They currently operate under the so-called Community-Led Local Development framework (Servillo and De Bruijn 2018), which emphasizes the participation of local residents in both local development strategies planning and implementation (Furmankiewicz et al. 2015; Chmieliński et al. 2018; Müller et al. 2020). This model of local resources management is implemented in all EU countries. According to Ray (2006) this approach has two primary characteristics: firstly, the valorisation and exploitation of physical and human local resources are used to maximize the benefits within the local territory; secondly, the principle and process of local participation in designing and implementing action are emphasized and the focus on local needs, capacities and perspectives of local people is highlighted. However, the EU support acts as an incentive for the local strategy makers to include the objectives of both the EU and the national rural development programmes. It is a feature peculiar to the place- 
based or neo-endogenous development concepts (Böcher 2008; Furmankiewicz 2012; Bowden and Liddle 2018).

The idea of partnerships involves the shift of public policy towards the re-positioning of local authorities as facilitators, rather than suppliers in meeting the local needs (Yarwood 2002). In contrast to ideal assumptions of the Community-Led Local Development and LEADER "inclusive" territorial governance (European Commission 2006, 2014), the subject literature offers a significant amount of information about the cases of 'governance failures', 'social exclusion' or ineffective local projects (European Court of Auditors 2010). Researchers have found the community participation as quite often contested or problematic (Edwards 1998; Jones and Little 2000). LAGs are sometimes dominated by the public sector, whereas the community interest remains on the margins of power (Furmankiewicz and Macken-Walsh 2016). However, many territorial partnerships achieve significant levels of social participation and success in local development (Petrick and Gramzow 2012).

On the one hand, the frequently elite-oriented nature of LAGs' management boards is a wellknown fact (Thuesen 2010), but on the other, in both many formal documents as well as research findings the key personnel of partnerships emphasizes their attempts to activate local people in conformity with the EU programming documents. They also observe small involvement of local residents. The typical explanation of these processes is due to the role of human and physical resources at the elites' disposal and their tendency to maintain own profitable domination (Lowndes and Sullivan 2004).

While the majority of authors focus on social capital or power relations between the stakeholders involved in LAGs, this paper attempts to discuss the role of needs and goals of both local residents and governing elites in the neo-endogenous development. It has been suggested that the achievement of specific EU objectives is often constrained by the differences between the goals of typical local residents and the aims of elites, resulting from their knowledge and/or interest. It has also been partly explained why, when even LAGs' board members make efforts to engage local residents in the partnerships activities, all they face is social indifference and passivity.

\section{The Role of Community Needs in Neo-endogenous Rural Development}

Cross-sectoral partnerships, e.g., LEADER type Local Action Groups, are considered to be an important tool to improve both governance and local citizens' participation in managing local resources in rural areas of European Union. They seek to improve policy co-ordination and adaptation to local conditions, which results in better utilization and targeting of programmes, integrates the civil society concerns into strategic planning carried out through more widespread participatory democracy, stimulates corporate involvement in local projects and promotes greater satisfaction with public policies. Among several main features of the LEADER type programmes listed in the literature (territorial approach, networking and cooperation, integrated and multisectoral actions, innovation promotion, public-private partnership) the most distinctive one is the bottom-up approach (European Commission, 2006, 2014). Local partnerships should create community-based strategies reflecting the resources and needs of local communities on the coherent territory, however, they should also show the conformity of local goals and actions with the national rural development programme based on the EU objectives, what can be considered as a conscious stimulation of the process of "Europeanization" (promotion of the convergence in economic rules, regulation, and policies in EU countries). According to the idea of the LEADER type programmes (e.g. the Community-Led Local Development), a partnership is developed and managed by the representatives of local communities originating from the public, voluntary and private sector, which should result in better management efficiency of local resources, thus constituting an important issue for the local government (Babczuk et al. 2017).

The view about positive outcomes of the local cross-sectoral cooperation in horizontal networks derives from the influential economic models presenting the advantages (benefits) of group efforts. The important background is provided by the second-generation models of rational choice theory which, after some modifications, offer empirical support for the explanation of human behaviour in a 
broad spectrum of substantive areas in sociology and political sciences (Hechter and Kanazawa 1997; Ostrom 1998). The new models emphasize rationality, both economic (goods or financial profit) and psychological (fulfilling individual needs such as satisfaction, respect of other people, etc.), as the factor implying a benefit-oriented behaviour. A rational choice is not based on logical reasoning alone. It is also influenced by an individual bias or schemas and can be modified in social interaction. The formal institutions (i.e. state administrative structures, law) and the informal ones (i.e. beliefs or local social norms) have a significant impact on the individual behaviour. Following the general opinion, people work most commonly to meet their individual needs, therefore the theories assuming the hierarchy of human needs could be used to explain the choices made.

Maslov's hierarchy of needs (Maslov 1943) represents the classical approach in behavioural sciences. It is often presented as a pyramid, with the largest and most fundamental levels of needs at the bottom (immediate physiological needs, safety, love) and the need for esteem and selfactualization at the top. This idea was criticized as ethnocentric (derived from the observation of an individualistic society), with an incorrect hierarchy, as assumed only rather than existing in reality. Kenrick et al. (2010) proposed an updated and revised hierarchy of human motives based on the theoretical and empirical developments at the interface of evolutionary biology, anthropology, and psychology. This hierarchy starts with the most important, for an individual, immediate physiological needs, through self-protection, affiliation, status/esteem, mate acquisition and retention, ending up with parenting. These needs are not met in a hierarchical order, but rather in an overlapping manner. It reflects the assumption that the early developing motives are unlikely to be totally replaced by later goals, but instead continue to be important throughout life, depending on individual differences and proximate ecological cues. The individual actions aimed at fulfilling one's own needs are influenced by knowledge and beliefs, which lead to the concept of constructivism. Constructivism is a theory of knowledge (epistemology) arguing that humans generate knowledge and meaning from an interaction between their experiences and ideas. It could also be referred to as the systems of knowledge schemas, which have a significant impact on human decisions. Following to this approach, ideas, identity and individual beliefs influence government leaders, businessmen and other local activists, playing a strong role in defining their interests (Halabi 2004).

According to Ostrom (1998) reputation, reciprocity and trust represent the core social relationships having a significant impact on the level of cooperation and finally on the common benefits. The role of trust is often analysed in terms of partnership governance, primarily in the context of government-third sector relations. Walsh (1998) emphasized that the local government in Ireland was mainly responsible for the physical development, when local partnerships were focused on socio-economic development, paying little attention to physical issues, which can lead to the conflict of interests. The negative result of incompatible stakeholders' goals was observed especially in the case of conflicts in spatial planning and investment localisation, most commonly between the local government, local communities and non-government organisations (Dubel and Królikowska 2014, Furmankiewicz et al. 2019). The public officials often advocate a narrow concept of development, focusing mainly on economic efficiency and ignoring the aspect of sustainability, participation and social needs (Dobbs and Moore 2002; Stanek 2016). In management practice, there are negative cases in which the potential of given territorial units is used very inefficiently by the local governments (Przybyła et al. 2020). These problems, to a lesser extent, also appear in the Local Action Groups. The differences of goals set by the central government and the local community constituted an important problem identified in exogenous development. In theory, bottom-up and cooperative approach used in neo-endogenous LEADER method (and Community-Led Local Development) should overcome that problem, however, power tensions described in literature also show the importance of conflicts of local stakeholder interests (Reed 1995). The authors of the paper intend to provide additional data to the debate on the role of differences in the needs and priorities of local stakeholders in the European Union development policy implementation at the local level. 


\section{Materials and Methods}

The discussion covering the consistency of goals set by the European Union, LAGs' governing elites and local residents is based on archival data from the questionnaire survey carried out in the years 2006-2007, and additional data about LAGs' main targets from 2011 and 2018 (conducted in 2012 and 2019, Table 1). The compared data were collected in different projects, therefore they do not have identical methodological features (e.g. analysed categories of goals). However, they allowed pre-comparing the main development priorities of different stakeholders, which can be useful in designing more detailed future research based on the standardised methodology. Some data was used in a different research conducted by the authors (Furmankiewicz and Królikowska 2010, Furmankiewicz and Campbell 2019), however, in this study the analysis is extended by collecting current data about the studied partnerships retrieved from their development strategies and official websites.

Table 1. Basic information on the archival and current data used in the paper.

\begin{tabular}{|c|c|c|c|}
\hline $\begin{array}{c}\text { Data } \\
\text { accuracy }\end{array}$ & $\begin{array}{l}\text { Year of data } \\
\text { collection }\end{array}$ & Methods used & Partly analysed in: \\
\hline 2006 & 2006-2007 & $\begin{array}{l}\text { - questionnaire survey addressed to local } \\
\text { residents in three case study partnerships } \\
\text { - questionnaire survey covering the key } \\
\text { partnership members in three case study } \\
\text { partnerships }\end{array}$ & $\begin{array}{l}\text { Furmankiewicz and } \\
\text { Królikowska } 2010 \\
\text { (only in Polish) }\end{array}$ \\
\hline 2011 & 2012 & $\begin{array}{l}\text { - the content analysis of local development } \\
\text { strategies of } 336 \text { LAGs }\end{array}$ & $\begin{array}{l}\text { Furmankiewicz and } \\
\text { Campbell, } 2019\end{array}$ \\
\hline 2018 & 2019 & $\begin{array}{l}\text { - the content analysis of local development } \\
\text { strategies of } 314 \text { LAGs } \\
\text { - the content analysis of national and case study } \\
\text { partnerships documents valid for 2014-2020 UE } \\
\text { Programming Period }\end{array}$ & $\begin{array}{l}\text { Furmankiewicz and } \\
\text { Campbell, 2019; }\end{array}$ \\
\hline
\end{tabular}

We focused on the three case study partnerships in Poland, presenting a relatively stable status in the period 2005-2019 (Table 2):

- "Leader of Strug Valley" LAG (in the paper referred to as the Strug Partnership), the case of cooperation established in mid-90s,

- "Odra River Riparian Land" LAG (formerly: Middle Odra River Partnership, in the paper - the Odra Partnership), the case of partnership initiated in the years 2000-2002 and supported by the US financial resources,

- "Pilica Valley" LAG (in the paper - the Pilica Partnership), the case of the youngest organisation established with the support of the LEADER Pilot Programme in years 2005-2006.

All three researched partnerships received funding from the Rural Development Programme in the European Union Programming Period 2007-2013 (4rd LEADER Axis) and in the Programming Period 2014-2020 (Community-Led Local Development).

We used archival data from the semi-structured in-depth interview method in all case study partnerships. In the years 2006-2007 the key representatives of local organisations in each LAG were interviewed in the study (N1=8 in Pilica Partnership; N2=15 in Strug Partnership, and N3=20 in Odra Partnership, the total of 43 interviews). The interviews consisted of open-ended and closed questions about the main targets of partnership members (so, according to them, what goals and actions should be carried out in the course of partnership work). The methodology based on interviews with the representatives of LAGs members or boards of directors is similar to the one used in the research of LAGs carried out by other authors in several case studies (Davies 2002; Nardone et al. 2010).

At the same time the authors conducted a questionnaire survey with the residents of rural areas on LAG territory. Its aim was to find out if the local needs are consistent with the goals of 
partnership leaders. The question about goals and actions used the same categories as in the questionnaires addressed to the LAGs boards' members. Due to budget constraints a quota sample N=200 (96 in Odra Partnership, 53 in Strug Partnership and 51 in Pilica Partnership) was used. The survey was conducted in the randomly selected village administrative units ("solectwo"), max. 5 respondents in a unit. The individuals were selected to represent same gender and age share in a sample as in the complete LAG rural population (according to the data from the Statistics Poland). This is not a random sample (thus, it is not a representative sample), however, it provides satisfying results in the low budget exploratory studies (Babbie 2011).

Table 2. Basic information about case study partnerships.

\begin{tabular}{|c|c|c|c|c|}
\hline \multicolumn{2}{|l|}{ Feature } & STRUG & ODRA & PILICA \\
\hline \multicolumn{2}{|c|}{$\begin{array}{r}\text { Year of establishment of cross-sectoral co- } \\
\text { operation (first agreement) }\end{array}$} & 1994 & 2002 & 2006 \\
\hline \multicolumn{2}{|c|}{ Year of LAG registration } & 2006 & 2005 & 2006 \\
\hline \multirow{3}{*}{ Number of member municipalities } & 2007 & 4 & 10 & 2 \\
\hline & 2011 & 4 & 12 & 10 \\
\hline & 2015 & 4 & 12 & 15 \\
\hline \multirow{3}{*}{ Number of members } & 2007 & 30 & 21 & 15 \\
\hline & 2011 & 36 & 40 & 120 \\
\hline & 2015 & 46 & 79 & 174 \\
\hline \multicolumn{2}{|c|}{ Area in square km (2019) } & 276 & 1,880 & 2,091 \\
\hline \multicolumn{2}{|l|}{ Number of residents (2013) } & 36,028 & 124,957 & 111,791 \\
\hline
\end{tabular}

We also used the data from LAGs strategies valid for the EU 2007-2013 Programming Period ( $N=336$ analysed LAGs, funded by the Rural Development Programme Axis 4) and for 2004-2020 ( N=314 analysed LAGs, funded either by the Rural Development Programme or by the Operational Programme "Fisheries"). The authors analysed the content of formal strategic documents ("social artefacts"). This methodology is often used in the studies on policy implementation at various administrative levels (regional, national, European) and also in social sciences (Babbie 2011; Boukalova et al. 2016; Krajewski and Solecka 2019).

\section{Results: Comparison of Goals}

The EUROPE 2020 strategy identified five main targets to enhance growth and employment in the years 2010-2020 (European Commission 2010), which can be summarized as follows:

To increase the employment rate of the population aged $20-64$ to $\min .75 \%$.

To increase investments to min. 3\% of the EU GDP in the "Research and Development", mainly by improving the conditions for these investments in the private sector and develop a new indicator to track innovation.

To reduce greenhouse gas emissions by at least $20 \%$ compared to 1990 levels, to achieve min. $20 \%$ share of renewable energy in final energy consumption and min. $20 \%$ increase in energy efficiency.

To reduce the share of early school leavers to $10 \%$ and increase the share of population aged 30 34 having completed the tertiary education to at least $40 \%$.

To decrease the number of Europeans living below the national poverty level by $25 \%$ and lift 20 million people out of poverty.

These goals were transferred indirectly to Polish Rural Development Programme 2014-2020 (RDP), which supports the Local Action Groups. The specific priorities to be taken into account in all national RDPs were specified in Article 5 of the EU Regulation No 1305/2013: "1. Fostering knowledge transfer and innovation in agriculture, forestry, and rural areas; 2. Enhancing farm viability and competitiveness of all types of agriculture in all regions and promoting innovative farm technologies and the sustainable management of forests; 3. Promoting food chain organisation, 
including processing and marketing of agricultural products, animal welfare and risk management in agriculture; 4 . Restoring, preserving and enhancing ecosystems related to agriculture and forestry; 5. Promoting resource efficiency and supporting the shift towards a low carbon and climate resilient economy in agriculture, food and forestry sectors; 6. Promoting social inclusion, poverty reduction and economic development in rural areas". These priorities include the total of 18 detailed objectives. Polish RDP set out 12 of its own development "needs" (Ministry of Agriculture and Rural Development, 2019), which are to meet the total of 18 specific objectives from the Regulation 1305/2013 and 3 cross-cutting objectives (environment; mitigation and adaptation to climate change; innovations). According to the authors, Polish RDP document is highly specialized and may not be easily understood by an average resident of rural areas participating in the local strategy preparation. It may even be difficult to understand clearly what goals are to be achieved (12 national "needs", 6 EU "priorities" with 18 "specific objectives" or/and 3 "cross-cutting objectives"?). As a result, local residents could have a problem adjusting their documents to the recommendations of this overarching programme, even if they planned to do so. The main goals of the Europe 2020 strategy are much more explicit and also more specific to every reader.

Each LAG, while developing their strategies, had to show that local activities are consistent with the objectives of the overarching national support programme, which is one of the features of the neo-endogenous and place-based development (Van Depoele 2003; Böcher 2008; Furmankiewicz 2012; Bosworth et al. 2016). It should be remembered, however, that partnerships do not take over the local governments' competencies in the field of public services and the development of local infrastructure. They are rather oriented towards additional activities, incurring much lower costs, where attention is paid to the projects stimulating local communities, including local small entrepreneurs and the third sector. However, according to the procedures of the supporting programme, these small projects, meeting local needs, should take into account the paramount objectives, indirectly resulting from the EU development objectives.

In the research conducted before the EUROPE 2010-2020 strategy period, the authors found significant differences between the main activities carried out by the institutional members of partnerships and the local residents' needs in three case study partnerships (Figure 1). For the local residents of rural areas technical and living infrastructure (roads, water and gas networks) were the most important, whereas partnerships typically do not perform this kind of tasks (however, in some partnerships municipal investments were sometimes taken into account in strategies). Similarly, the significant differences were observed in the categories of environmental infrastructure (sewerage networks, sewage treatment plants, waste management) and "health and rescue missions" (it also covers public health care) and "social problems solving".

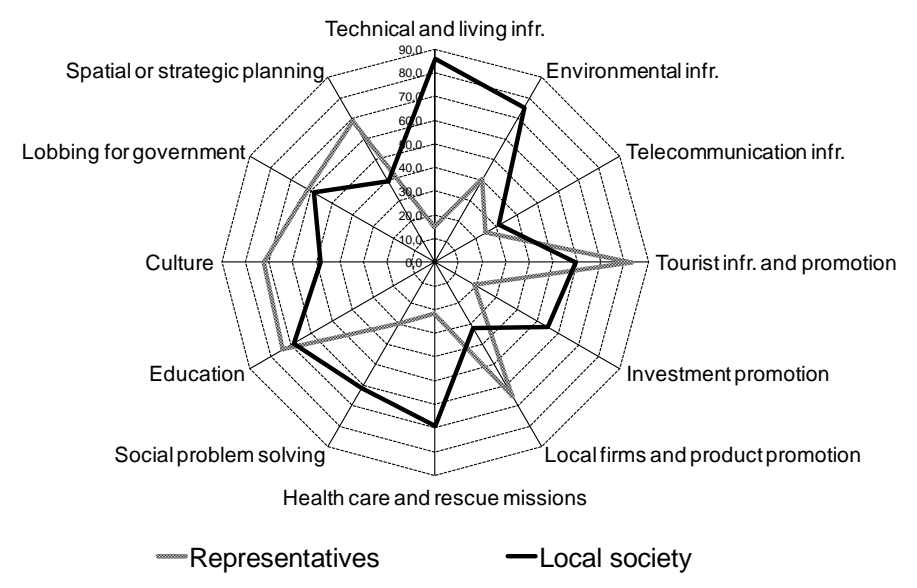

Figure 1. The issues important for partnerships' institutions representatives ("Representatives") and for the local residents ("Local society") in three case studies of partnership before the Europe 2020 strategy period. The sum of the answers "very important" and "important" in the percentage of all answers (statistical mean value). 
The residents focused predominantly on biophysical needs (health, technical comfort of leaving). Partnerships operated as a kind of local development agencies, mainly supporting the technical and productive needs (tourism development, local business development etc.). The governing elites in partnerships highly assessed the promotion of local products. It was an important goal for almost half of administrative units in the case study of partnerships, whereas only $9 \%$ of residents considered it important. The elites were more interested in economic development related to entrepreneurship or farming activities and the development of products and services for both local and external actors. This seems to be reasonable and in line with the EU strategy, however, it was not of a major importance for a typical local resident. On the contrary, solving social problems (such as e.g. poverty and social exclusion, very important issues in the EU) were important for the local communities and less significant for the elite managing partnerships. Perhaps they assumed that the development of entrepreneurship and employment growth would automatically contribute to the reduction of social problems (poverty, social exclusion). This may be an important reason for the failure of the partnership to improve the involvement of the local community in the work of the partnership, almost as important as the power relations resulting in the dominance of local governments. Local residents do not engage in the activities considered unimportant for the community reality. In turn, it is difficult to achieve welfare in rural areas by meeting only the typical needs connected with the living conditions or health care issues, especially that partnerships do not focus on such goals in their work.

In the opinion of individual respondents, the municipal infrastructure development, environmental issues and health care remained the priority. Sewage construction and waste management were predominantly recognized as the environmental infrastructure. It was not in compliance with the goals identified by the partnership institutional members, which mainly related to the tourism promotion and infrastructure development, cultural issues and local product promotion. Only education (especially of children) was important for both the local residents and governing elites to a similar extent.

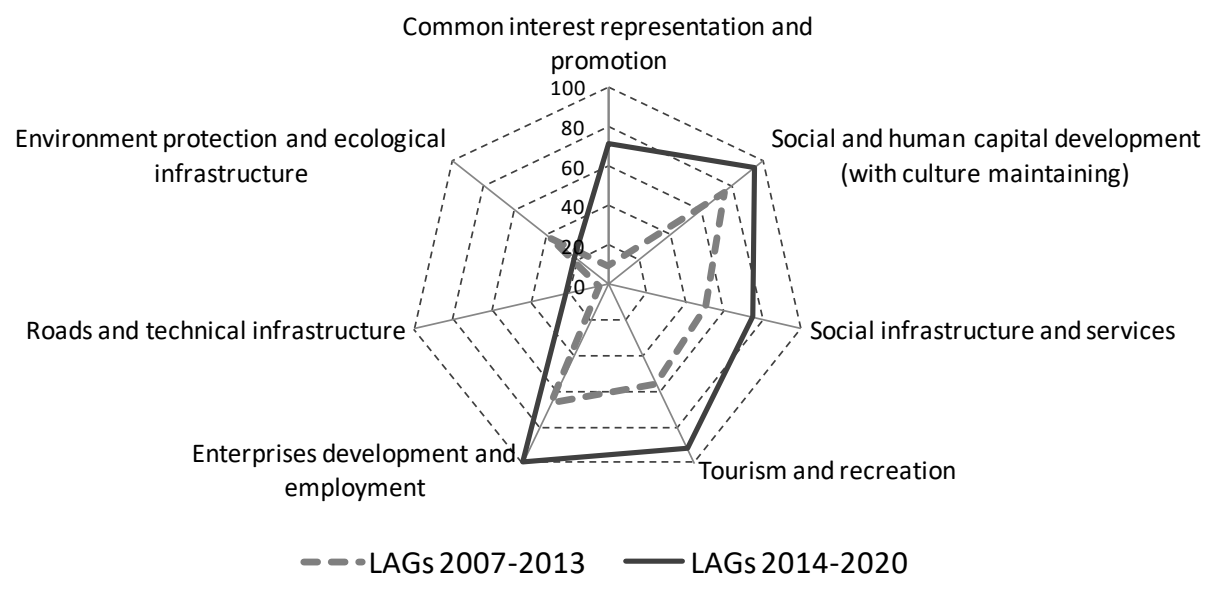

Figure 2. The main goals of rural development partnerships (LAGs) in Poland in the EU Programming Period 2007-2013 ( $\mathrm{N=336)}$ and 2014-2020 ( $\mathrm{N}=314$ ). The diagram shows the percentage of strategies referring to a given issue in the priority targets.

The analysis of the goals presented in the strategies (Figure 2) indicates that they show some specialization, comparing to the general social needs. They could be highly consistent with the EU goals in the field of entrepreneurship and social issues (education and fighting social exclusion). However, the environmental issues, including those related to renewable energy sources and reduction of greenhouse gases emissions, were not among the priorities of LAG's activities. For instance, the analysis of local strategies indicates that the local coal and wood stoves, in which residents often burn rubbish, were not perceived as a significant ecological threat. Local projects frequently focused on the preservation of cultural heritage (traditions, local products, historic 
monuments) as the base for tourism development and were hardly associated with innovative investments in research and development. These elements were also noticeable in the main goals of the three partnerships analyzed (Table 3). For example, only Odra Partnership took into consideration the "Development of infrastructure and education programmers related to ecology and nature, including the Renewable Energy Sources (RES)" in detailed goals, whereas in the case of Strug and Pilica Partnership the development of local RES was not included in the strategy targets. All three partnerships focused on sustaining the local cultural and historical heritage, hence, a very "traditional" development. However, they also took into account human and social capital development problems as well as the support for local business, which seems to be in line with the EU objectives.

Table 3. The main goals specified in the case study of LAGs' strategies in the 2014-2020 EU Programming Period.

\begin{tabular}{ccl}
\hline LAG & $\begin{array}{c}\text { Strategy } \\
\text { period }\end{array}$ & \multicolumn{1}{c}{ Main goals } \\
\hline STRUG & $2016-2022$ & $\begin{array}{l}\text { 1. Active and creative residents; 2. Support for economic development } \\
\text { through innovative and pro-ecological activities; 3. Strengthening the } \\
\text { attractiveness of the region by using cultural, tourist, historical resources } \\
\text { and promoting local products. }\end{array}$ \\
\hline ODRA & $2015-2023$ & $\begin{array}{l}\text { 1. Preservation of the natural and cultural heritage of the area based on the } \\
\text { entrepreneurship of residents and the development of tourism in the } \\
\text { region; 2. Building an integrated, educated and active civil society and } \\
\text { increasing the residents' sense of identity with the LAG region. }\end{array}$ \\
\hline PILICA & $2014-2020$ & $\begin{array}{l}\text { 1. Developing tourist, recreational and cultural infrastructure; } 2 . \\
\text { Supporting historical and cultural heritage and artistic creativity; } 3 . \\
\text { Promotion of the area, including local products and services. }\end{array}$ \\
\hline
\end{tabular}

\section{Discussion: Local Partnerships - the Tool of the EU Policy and/or the Instrument for Meeting Social Needs?}

The literature indicates that top-down programmes may be inefficient in solving social problems such as unemployment or low social activity (Willis 2005; Chruscinski et al. 2019; Hełdak et al. 2018). Neo-endogenous initiatives are meant to be a remedy for this problem by defining the needs and priorities of actions at grassroots, but partially steered by external, national or the EU goals (Ray 2006). In turn, however, bottom-up initiatives may hamper the implementation of supralocal goals, when the local community is not interested in achieving the abstract external targets, like biodiversity conservation, Natura 2000 sites or integrated water management (Dubel et al. 2013; Dubel and Królikowska, 2014). Similarly, such goals as mitigating climate change and development of renewable energy sources were not important for the analysed LAGs.

The European and even local governing elites involved in territorial partnerships can have a different hierarchy of development priorities than the "average" citizen. This may result from the usually higher level of education or the social status achieved by the governing elites, compared to the probably lower average education, status and income of the typical rural areas residents, which was visible in Poland (Furmankiewicz et al. 2016; Czapiewski and Janc 2019). Similarly, Thuessen et al. (2010) observed, based on the survey covering the Local Action Groups in Danmark, that the majority of board members were extremely well-educated older men holding other significant positions in society. Even when there exists evidence suggesting a widespread involvement, partnership structures often established relations with only a limited number of individuals or the community interest groups organized by active, affluent, often well-educated local citizens representing specific community interests rather than the community as a whole (Jones 2002). Ostrom and Ostrom (1977, p. 34) state that "when professional personnel presume to know what is good for people rather than providing people with the opportunity to express their own preferences, we should not be surprised to find that increasing professionalization of public services is 
accompanied by a serious erosion in the quality of those services". Public managers often represent the dominant group in partnership boards, thus excluding the general public from formal partnership boards, however, they have high qualifications for management and administrative work (Munro et al. 2008; Furmankiewicz and Macken-Walsh 2016). In theory partnership arrangements can work to "join up" the dispersed service providers along with harnessing the distinct contributions that different agencies can make to meet the diverse and complex local needs, including social exclusion (Lowndes and Sullivan 2004). The clash of interests is smaller at the local level, however, it does exist, making the wide implementation of the "external" EU goals more difficult.

Dobbs and Moore (2002) emphasize that even if policy makers and practitioners attempted to adopt a more bottom-up, community centred approach in local planning and regeneration, frequently the requirements of local authorities and other partners to involve local communities provided neither the time nor the resources to support this involvement. Overall, a general failure to get the public involved in the development policy was often observed. Local authorities and government clerks, representing the significant part of local elites, are in the possession of the main financial resources, remain the dominant player, with other partners often playing just minor roles. Community actors are also generally less powerful, having smaller resources at their disposal in terms of finance, time, tools and experience to empower themselves and compete at the same level, often dependent on local authorities' support, which was also visible in Poland (Furmankiewicz 2013; Furmankiewicz and Macken Walsh 2016).

The infrastructure modernisation, most frequently listed by the local residents as an important issue, often does not generate any development incentives and changes in individual enterprises, as observed by Gorzelak in the case of the Local Initiative Programme implemented in mid-90s in several municipalities in Poland (Gorzelak 2000). However, the evolution of partnerships shows that the social issues and local small business needs are becoming an increasingly important topic of territorial cooperation in Poland, especially in cross-sectoral partnerships (Furmankiewicz and Campbell 2019).

Currently the neo-endogenous model of local community development is not limited to rural areas alone. Since 2015 Urban Local Action Groups have also been established in Poland, although their focus is primarily on social issues. However, they could support solving social problems like social exclusion resulting from, e.g., poverty or disability (Świąder et al. 2016) and the development of various types of strategic and planning documents related to land management issues, investment location or urban sprawl (Zajda et al. 2017).

\section{Conclusions}

The presented paper addresses the differences between the goals included in the EU programming documents, LAGs' strategies, the goals of local elites and LAGs' residents. The local residents, typically featuring lower education and income level than the elites, paid more attention to the immediate physiological needs and self-protection (thus, perceived technical living infrastructure and public services as the most important) as well as sustaining local heritage. The active elites, typically with higher education, status and probably income, based their goals on the rational conviction that stimulating economic activity of local residents, innovations and diversification of local economy are more important for the local development. These differences are in line with the new models of the hierarchy of needs (Kenrick et al. 2010) and could have some impact on social passivity and social engagement in partnerships work. If the EU goals are to be effectively implemented, it is important to bring the social goals and targets set by the educated elites closer together. It is the objective of neo-endogenous development concept (Ray 2006; Böcher 2008). LAGs' strategy can be considered a compromise between the interests of the strongest local stakeholders and top-down national or European policies (Bosworth et al. 2016). The promotion of the new comanagement methods could also help in determining the local development goals and actions (Pappalardo et al. 2018). However, the innovative development based on local needs and goals can also be limited by the local norms and habits (Halabi 2004). It can remain a significant constraint in 
implementing the European strategies and policies. An extensive promotion of the importance of the EU development goals as well as the educational activities raising the residents' awareness of how the local activities are linked to the development processes at both national and global level, are indispensable to overcome these problems.

Acknowledgments: This conference paper was prepared within the framework of the initial stage of the project No. 2019/33/B/HS4/00176 (OPUS 17) financed by the National Science Centre in Poland, however, it was also based on the archival data collected by the Authors in the course of other projects.

\section{References}

Adamski Tomasz and Gorlach Krzysztof. 2007. Neo-Endogenous Development and the Revalidation of Local Knowledge. Polish Sociological Review: 160(4), 481-497. https://www.jstor.org/stable/41275036.

Babbie Earl. 2011. The Basics of Social Research. 5th ed. Wadsworth: Cengage Learning.

Babczuk Arkadiusz, Kachniarz Marian, and Piepiora Zbigniew. 2017. Work efficiency of local governments. In Hradec Economic Days, Vol. 7(1), Double-blind peer-reviewed proceedings of the international scientific conference Hradec Economic Days 2017. Hradec Králové: University of Hradec Králové, pp. 20-28. Available online: https://uni.uhk.cz/hed/site/assets/files/1046/proceedings_2017_1.pdf.

Böcher Michael. 2008. Regional Governance and Rural Development in Germany: the Implementation of LEADER+. Sociologia Ruralis: 48(4), 372-388. https://doi.org/10.1111/j.1467-9523.2008.00468.x.

Bosworth Gary, Annibal Ivan, Carroll Terry, Price Liz, Sellick Jessica, and Shepherd John. 2016. Empowering Local Action through Neo-Endogenous Development; The Case of LEADER in England. Sociologia Ruralis: 56(3), 427-449. https://doi.org/10.1111/soru.12089.

Boukalova Katerina, Kolarova Alena, and Lostak Michal. 2016. Tracing shift in Czech rural development paradigm (Reflections of Local Action Groups in the media). Agricultural Economics - Zemědělská ekonomika: 62(4), 149-159. https://doi.org/10.17221/102/2015-AGRICECON.

Bowden Alistair, and Liddle Joyce. 2018. Evolving public sector roles in the leadership of place-based partnerships: from controlling to influencing policy? Regional Studies: 52(1), 145-155. https://doi.org/10.1080/00343404.2017.1346369.

Chmieliński Paweł, Faccilongo Nicola, Fiore Mariantonietta, and La Sala Piermichele. 2018. Design and implementation of the Local Development Strategy: a case study of Polish and Italian Local Action Groups in 2007-2013. Studies in Agricultural Economics: 120(1), 25-31. https://doi.org/10.7896/j.1726.

Chruscinski Jakub, Kazak K. Jan, Tokarczyk-Dorociak Katarzyna, Szewranski Szymon, and Swiader Malgorzata. 2019. How to Support Better Decision Making for Sustainable Development? IOP Conference Series: Materials Science and Engineering: 471(112008), pp. 1-9. https://iopscience.iop.org/article/10.1088/1757899X/471/11/112008.

Czapiewski Konrad, and Janc Krzysztof. 2019. Education, Human Capital and Knowledge-The Paradigm Shift and Future Scenarios on Polish Rural Areas. In Three Decades of Transformation in the East-Central European Countryside. Berlin: Springer, pp. 351-367. https://link.springer.com/chapter/10.1007/978-3-030-21237-7_16.

Davies R. Anna. 2002. Power, politics and networks: Shaping partnerships for sustainable communities. Area: 34(2), 190-203. https://doi.org/10.1111/1475-4762.00071.

Dobbs Lynn, and Moore Craig. 2002. Engaging Communities in Area-based Regeneration: The Role of Participatory Evaluation. Policy Studies: 23(3/4), 157-171. https://doi.org/10.1080/0144287022000045966.

Dubel Anna, Jamontt-Skotis Marta, Królikowska Karolina, Dubel Krzysztof, and Czapski Michał. 2013. Metody rozwiazywania konfliktów ekologicznych na obszarach Natura 2000. Stowarzyszenie Centrum Rozwiązań Systemowych: Wrocław-Kraków.

Dubel Anna, and Królikowska Karolina. 2014. Nature conservation versus flood protection-participatory conflict resolution for the Białka River Valley. Economic and Environmental Studies: 14(4), 473-484. http://www.ees.uni.opole.pl/content/04_14/ees_13_4_fulltext_09.pdf.

Edwards Bill. 1998. Charting the Discourse of Community Action: Perspectives from Practice in Rural Wales. Journal of Rural Studies, 14(1), 63-77. https://doi.org/10.1016/S0743-0167(97)00048-X.

European Commission. 2006. The LEADER approach: a basic guide. Luxembourg: Office for Official Publications of the European Communities. https://enrd.ec.europa.eu/sites/enrd/files/2B953E0A-9045-2198-8B09ED2F3D2CCED3.pdf.

European Commission. 2010. Europe 2020. A strategy for smart, sustainable and inclusive growth, Communication from the Commission 3.3.2010 COM(2010). Brussels: European Commission. 
European Commission. 2014. Community-Led Local Development. Brussels: European Commission. https:/ec.europa.eu/regional_policy/sources/docgener/informat/2014/community_en.pdf

European Court of Auditors. 2010. Implementation of the LEADER approach for rural development. Luxembourg: European Court of Auditors. https://www.eca.europa.eu/Lists/ECADocuments/SR10_05/SR10_05_EN.PDF

Furmankiewicz Marek. 2012. LEADER+ territorial governance in Poland: Successes and failures as a rational choice effect. Tijdschrift voor Economische en Sociale Geografie: 103(3), 261-275. https://doi.org/10.1111/j.14679663.2011.00680.x.

Furmankiewicz Marek, and Campbell Adrian. 2019. From Single-Use Community Facilities Support to Integrated Sustainable Development: The Aims of Inter-Municipal Cooperation in Poland, 1990-2018. Sustainability: 11(5890), 1-21. https://doi.org/10.3390/su11215890.

Furmankiewicz Marek, Janc Krzysztof, and Macken-Walsh Áine. 2016. The impact of EU governance and rural development policy on the development of the third sector in rural Poland: A nation-wide analysis. Journal of Rural Studies: 43, 225-234. https://doi.org/10.1016/j.jrurstud.2015.12.011.

Furmankiewicz Marek, Knieć Wojciech, and Atterton Jane. 2015. Rural governance in the new EU member states: The experience of the Polish LEADER+ Pilot Programme (2004-2008). In Governance in Transition. Dordrecht: Springer Geography, pp. 133-153. https://link.springer.com/chapter/10.1007/978-94-007-55031_7.

Furmankiewicz Marek, and Królikowska Karolina. 2010. Partnerstwa terytorialne na obszarach wiejskich w Polsce w latach 1994-2006. Wrocław: Wydawnictwo Uniwersytetu Przyrodniczego we Wrocławiu.

Furmankiewicz Marek, and Macken-Walsh Áine. 2016. Government within governance? Polish rural development partnerships through the lens of functional representation. Journal of Rural Studies: 46, 12-22. https://doi.org/10.1016/j.jrurstud.2016.05.004.

Furmankiewicz Marek, Potocki Jacek, and Kazak Jan. 2019. Land-Use Conflicts in the Sudetes, Poland. IOP Conference Series: Materials Science and Engineering: 471(092033), 1-10. https://iopscience.iop.org/article/10.1088/1757-899X/471/9/092033.

Gorzelak Grzegorz. 2000. Zewnętrzna interwencja jako czynnik rozwoju lokalnego (na przykładzie Programu Inicjatyw Lokalnych). Studia Regionalne $i \quad$ Lokalne: 3(3), 99-120. http://www.euroreg.uw.edu.pl/dane/web_euroreg_publications_files/4819/2000_3_gorzelak.pdf.

Halabi Yakub. 2004. The Expansion of Global Governance into the Third World: Altruism, Realism, or Constructivism? International Studies Review: 6(1), 21-48. https://doi.org/10.1111/j.1079-1760.2004.00371.x.

Hechter Michael, and Kanazawa Satoshi. 1997. Sociological Rational Choice Theory. Annual Review of Sociology: 23, 191-214. https://doi.org/10.1146/annurev.soc.23.1.191.

Hełdak Maria, Stacherzak Agnieszka, and Przybyła Katarzyna. 2018. Demand and Financial Constraints in Eliminating Architectural and Technical Barriers for People with Disabilities in Poland. Journal of Healthcare Engineering: 2018(1297396), 1-9. https://doi.org/10.1155/2018/1297396.

Jones Owain, and Little Jo. 2000. Rural Challenge(s): partnership and new rural governance. Journal of Rural Studies: 16, 171-183. https://doi.org/10.1016/S0743-0167(99)00058-3.

Kenrick T. Douglas, Griskevicius Vladas, Neuberg L. Steven, and Schaller Mark. 2010. Renovating the Pyramid of Needs: Contemporary Extensions Built Upon Ancient Foundations. Perspectives on Psychological Science: 5(3), 292-314. https://doi.org/10.1177/1745691610369469.

Krajewski Piotr, and Solecka Iga. 2019. Management System of Urban Landscape in Poland on the Example of Wroclaw in the Context of European Landscape Convention Implementation. IOP Conference Series: Materials Science and Engineering: 471(112035), 1-10. https://iopscience.iop.org/article/10.1088/1757899X/471/11/112035.

Lowndes Vivien, and Sullivan Helen. 2004. Like a Horse and Carriage or a Fish on a Bicycle: How Well do Local Partnerships and Public Participation go Together? Local Government Studies: 30(1), 51-73. https://doi.org/10.1080/0300393042000230920.

Maslov H. Abraham. 1943. A Theory of Human Motivation. Psychological Review: 50, $370-396$. https://doi.org/10.1037/h0054346.

Ministerstwo Rolnictwa i Rozwoju Wsi. 2019. Program Rozwoju Obszarów Wiejskich 2014-2020 (PROW 2014-2020). Warszawa: Ministerstwo Rolnictwa i Rozwoju Wsi. https://www.gov.pl/web/rolnictwo/-program-rozwojuobszarow-wiejskich-2014-2020-prow-2014-2020.

Munro Hugh, Roberts Mark, and Skelcher Chris. 2008. Partnership governance and democratic effectiveness: Community leaders and public managers as dual intermediaries. Public Policy and Administration: 23(1), 6179. https://doi.org/10.1177/0952076707083286. 
Müller Oliver, Sutter Ove, and Wohlgemuth Sina. 2020. Learning to LEADER. Ritualised Performances of 'Participation' in Local Arenas of Participatory Rural Governance. Sociologia Ruralis: 60(1), 222-242. https://doi.org/10.1111/soru.12287.

Nardone Gianluca, Sisto Roberta, and Lopolito Antonio. 2010. Social Capital in the LEADER Initiative: a methodological approach. Journal of Rural Studies: 26(1), 63-72. https://doi.org/10.1016/j.jrurstud.2009.09.001.

Ostrom Elinor. 1998. A Behavioral Approach to the Rational Choice Theory of Collective Action. The American Political Science Review: 92(1), 1-22. https://doi.org/10.2307/2585925.

Ostrom Vincent, and Ostrom Elinor. 1977. Public Goods and Public Choices. In Alternatives for Delivering Public Services: Toward Improved Performance. Boulder, CO: Westview Press, pp. 7-49.

Pappalardo Gioacchino, Sisto Roberta, and Pecorino Biagio. 2018. Is the Partnership Governance Able to Promote Endogenous Rural Development? A Preliminary Assessment Under the Adaptive CoManagement Approach. European Countryside: 10 (4), 543-565. https://doi.org/10.2478/euco-2018-0031.

Petrick Martin, and Gramzow Andreas. 2012. Harnessing Communities, Markets and the State for Public Goods Provision: Evidence from Post-Socialist Rural Poland. World Development: 40(11), 2342-2354. https://doi.org/10.1016/j.worlddev.2012.03.007.

Przybyła Katarzyna, Kachniarz Marian, and Ramsey David. 2020. The investment activity of cities in the context of their administrative status: A case study from Poland. Cities: 97(2020), 1025052. https://doi.org/10.1016/j.cities.2019.102505.

Ray Christopher. 2006. Neo-endogenous rural development in the EU. In Handbook of Rural Studies. London: Sage. pp. 278-291. https://doi.org/10.4135/9781848608016.n19.

Reed G. Maureen. 1995. Cooperative Management of Environmental Resources: A Case Study from Northern Ontario, Canada. Economic Geography: 132-149. https://www.tandfonline.com/doi/abs/10.2307/144355.

Regulation (EU) No 1307/2013 of the European Parliament and of the Council of 17 December 2013 establishing rules for direct payments to farmers under support schemes within the framework of the common agricultural policy and repealing Council Regulations (EC) No 637/2008 and (EC) No 73/2009.

Servillo Loris, and De Bruijn Martijn. 2018. From LEADER to CLLD: The Adoption of the New Fund Opportunities and of Their Local Development Options. European Structural and Investment Funds Journal: 6(3), 223-233. https://estif.lexxion.eu/data/article/13233/pdf/estif_2018_03-007.pdf.

Shucksmith Mark. 2000. Endogenous development, social capital and social inclusion: perspectives from LEADER in the UK. Sociologia Ruralis: 40(2), 208-218. https://doi.org/10.1111/1467-9523.00143.

Słupińska Monika. 2013. Place-Based Approach in New Cohesion Policy. Studia Ekonomiczne: 149, 212-222.

Stanek Leszek. 2016. The spatial development of undeveloped real estate in the Wrocław district. Journal of Ecological Engineering: 17(4), 203-208. https://doi.org/10.12911/22998993/64551.

Świąder Małgorzata, Szewrański Szymon, and Kazak Jan. 2016. Spatial-Temporal Diversification of Poverty in Wroclaw. Procedia Engineering: 161, 1596-1600. https://doi.org/10.1016/j.proeng.2016.08.632.

Thuesen A. Anette. 2010. Is LEADER Elitist or Inclusive? Composition of Danish LAG Boards in the 2007-2013 Rural Development and Fisheries Programmes. Sociologia Ruralis: 50(1), 31-45. https://doi.org/10.1111/j.1467-9523.2009.00500.x.

Van Depoele Laurent. 2003. From Sectoral to Territorial-Based Policies: The Case of LEADER. In The Future of Rural Policy. From Sectoral to Place-based Policies in Rural Areas. Paris: Organisation for Economic Cooperation and Development, pp 79-87.

Walsh Jim. 1998. Local development and local government in the Republic of Ireland: From fragmentation to integration. Local Economy: 12(4), 329-341. https://doi.org/10.1080/02690949808726408.

Willis Katie. 2005. Theories and Practices of Development. Oxon-New York: Routledge.

Yarwood Richard. 2002. Parish councils, partnership and governance: the development of 'exceptions' housing in the Malvern Hills District, England. Journal of Rural Studies: 18(3), 275-291. https://doi.org/10.1016/S07430167(01)00042-0.

Zajda Katarzyna, Kołomycew Anna, Sykała Łukasz, and Janas Karol. 2017. Leader and Community-Led Development Approach. Polish Experiences. Łódź: Wydawnictwo Uniwersytetu Łódzkiego. 